\title{
ROLE OF THE CONCENTRATION PROCESS IN THE RECOVERY OF CANDIDA ALBICANS FROM BLOOD
}

\author{
Ana Lúcia Peixoto de Freitas ${ }^{1^{*}}$ and Afonso Luis Barth ${ }^{2}$ \\ ${ }^{1}$ Faculdade de Farmácia da Universidade Federal do Rio Grande do Sul, Escola de Farmácia da Universidade \\ Católica de Pelotas, Instituto de Cardiologia do Rio Grande do Sul; ${ }^{2}$ Faculdade de Farmácia da Universidade \\ Federal do Rio Grande do Sul, Unidade de Microbiologia do Hospital de Clínicas de Porto Alegre. Porto \\ Alegre, RS, Brasil
}

Submitted: April 15, 1998; Returned to authors for corrections: September 24, 1998; Approved: November 12, 1998.

\begin{abstract}
The lysis-centrifugation system (Isolator ${ }^{\mathrm{TM}}$ ) is recognized as the standard method for recovery of Candida spp. from blood. In this study, the effect of the concentration process of this system was compared with conventional methods of blood culture using liquid and biphasic media. The tests were performed in vitro using Candida albicans in counts of $100,10,1$, and 0.5 cells $/ \mathrm{ml}$ of blood. Cultures onto chocolate agar were performed with the sediment obtained after centrifugation of Isolator ${ }^{\mathrm{TM}}$ tube and with liquid and biphasic media after their incubation for $24 \mathrm{~h}$ at $35^{\circ} \mathrm{C}$. Gram stain prepared from the conventional methods were also evaluated in the first $24 \mathrm{~h}$. It was possible to detect Candida albicans in blood, regardless both the number of cells or methodology. As blastoconidia were observed in Gram stains at the same time that growth was noted, time for diagnosis was also not different for the compared methods. Therefore, we suggest that the process of concentration is not the single important factor responsible for the recovery rates of Candida albicans from blood by the Isolator ${ }^{\mathrm{TM}}$ system.
\end{abstract}

Key words: candidemia, blood culture, lysis-centrifugation system

\section{INTRODUCTION}

The incidence of fungemia has increased considerably in hospitalized patients $(1,21,28)$. Candida spp. are the most commonly fungi recovered from blood, and more than $50 \%$ of the episodes of candidemia are due to Candida albicans $(25,31)$. In fact, deep fungal infection due to Candida spp. is responsible for an excess of hospital stay and for an overall mortality rate that may range from $38 \%$ to $75 \%(32,33)$. Patients using inadequate antimicrobial treatment had a mortality rate higher than those receiving appropriate antifungal therapy $(24,30)$. Considering that patients with fungemia rarely present characteristic clinical manifestations, the diagnosis relies upon the findings of the microbiology laboratory, in particular, observation and isolation of fungi from blood. Although an increase in lifethreatening invasive yeast infection has been observed, many of these infections either remain undetected or are detected too late to beneficiate patient management $(4,21,22,23)$. The number of fungal cells in blood is generally small, and this poses the major problem to obtain a positive result $(27,4)$.

\footnotetext{
* Corresponding author. Mailing address: Departamento de Análises, Faculdade de Farmácia, UFRGS, Av. Ipiranga, 2752, CEP 90610-000, Porto Alegre, RS, Brasil. E-mail: c.f.osorio@pro.via-rs.com.br
} 
The conventional, visually monitored, broth-based blood culture consists of culturing blood in broth (liquid) or biphasic (liquid and solid) media. Their advantages include relative inexpensive supplies, the convenience of collecting specimens and most importantly, the benefits that can derive from the use of a technology that existed for so many years (12, 14). Therefore it is still largely used, specially in small laboratories.

The critical importance of sensivity and speed of processing blood cultures for proper diagnosis and management of patients stimulated continuous efforts to develop more sensitive blood culture methods. A great deal of work has been done to define optimal media, blood-to-medium ratios, types of anticoagulants and other routine procedures (12).

The development of a lysis-centrifugation system (Isolator; Wampole Laboratories, Cranbury, NJ) improved the recovery rates of fungi from blood. In this system blood cells are lysed to liberate microorganisms from phagocytes and blood is concentrated by centrifugation to prepare an inoculum that is plated onto agar plates. Most clinical comparisons of Isolator ${ }^{\mathrm{TM}}$ with broth-based blood culture systems showed higher sensitivity $(3,5,11$, $13,18,22)$, and earlier results using the Isolator ${ }^{\mathrm{TM}}$ system $(8,13)$. In a quantitative study, Kiehn et al. (15) reported advantage of Isolator ${ }^{\mathrm{TM}}$ versus broth culture method only if the number of fungal cells present in blood was less than $10 / \mathrm{ml}$.

Although lysis-centrifugation system has advantages, processing of specimens is laborintensive and expensive (18), mainly due to the centrifugation process rather than the lysis. Another disadvantage of Isolator ${ }^{\mathrm{TM}}$ is the high propensity for contamination due to manipulation of samples $(9,12)$.

Reports of Murray et al. (19) and Zierdt (35), comparing the of Isolator ${ }^{\mathrm{TM}}$ system with conventional broth method plus lytic agent, indicate that the higher performance Isolator ${ }^{\mathrm{TM}}$ is due to the release of intracellular microorganisms, so that broth supplemented with lytic agent saponin has been introduced in automated systems $(13,17)$.

The aim of this work is to evaluate the influence of blood concentration, using the Isolator ${ }^{\mathrm{TM}}$ system, in the recovery of Candida albicans.

\section{MATERIALS AND METHODS}

\section{Methods of blood culture and culture media}

The concentration process was done using the
Isolator ${ }^{\mathrm{TM}}$ system. Blood was concentrated by centrifugation using a fixed angle rotor, and the remaining pellet was directly plated onto solid media.

Tubes of Isolator ${ }^{\mathrm{TM}}$ contain saponin to liberate microorganisms from white blood cells and sodium polyanetholsulfonate (SPS) to prevent clotting. Although in vitro phagocytosis does not occur easily (16), in this study blood was mixed with the chemical components of the tube before inoculation of Candida albicans, in order to allow the action of SPS and saponin, avoiding "in vitro" phagocytosis (12). Therefore, the lysis interference was eliminated in all samples, assenting to determine the effect of the concentration alone.

The conventional methods were represented by biphasic bottles and by $45 \mathrm{ml}$ broth bottles, containing brain heart infusion (BHI - DIFCO Laboratories, Detroit, Michigan), supplemented with $0.05 \%$ SPS.

Chocolate agar plates used to subculture Candida albicans were prepared with BHI agar (DIFCO Laboratories, Detroit, Michigan).

\section{Blood}

A total of $30 \mathrm{ml}$ of blood was collected from healthy volunteers after appropriate desinfection of the venipuncture site. From each sample of blood a volume of $9 \mathrm{ml}$ was immediately inoculated into one Isolator $^{\mathrm{TM}}$ tube, one biphasic bottle and one broth bottle.

\section{Candida albicans}

Candida albicans isolated from a patient with candidemia, identified by API 20C (BIOMÉRIEUX VITEK, Missouri, USA), was maintained on agar slant at $22^{\circ} \mathrm{C}(20)$. The inoculation sample was prepared as described elsewhere $(2,6,16)$. Briefly, the sample was inoculated onto a chocolate agar plate and incubated for $24 \mathrm{~h}$ at $35^{\circ} \mathrm{C}$. Five to ten colonies were suspended in sterile saline and centrifuged for 10 minutes at 1,500 rpm. The pellet was washed twice and a suspension of turbidity equivalent to 1000 cells/ $\mathrm{ml}$ was prepared. The number of cells in this suspension was confirmed by counting the cells in Neubauer's chamber (7).

\section{Inoculation and culturing procedures}

The original suspension of 1000 cells of Candida albicans $/ \mathrm{ml}$ was serialy diluted to obtain an inoculum ten fold more concentrated than the final tests, i.e., 100,10 and 5 cells $/ \mathrm{ml}$. One $\mathrm{ml}$ of these suspensions was inoculated into each of the bottles or tubes, which 
had been previously inoculated with $9 \mathrm{ml}$ of blood. Accordingly, to perform tests with 100 cells of Candida $/ \mathrm{ml}$ of blood, $1 \mathrm{ml}$ of the suspension containing 1000 cells $/ \mathrm{ml}$ was used; to obtain tests containing 10 cells of Candida/ $\mathrm{ml}$ of blood the inocula with 100 cells $/ \mathrm{ml}$ was used, and so on.

After the inoculation of blood and suspensions of Candida albicans, the samples of conventional methods were incubated at $35^{\circ} \mathrm{C}$ for $24 \mathrm{~h}$. Subcultures were made as recommended (12): an amount was drain to prepare a Gram smear and a volume of $0.1 \mathrm{ml}$ was plated onto chocolate agar plates.

The Isolator ${ }^{\mathrm{TM}}$ tubes were processed as described in the instructions of the manufacturer (29). Finally, $0.1 \mathrm{ml}$ of the pellet was plated onto chocolate agar plates.

Chocolate agar plates were incubated at $35^{\circ} \mathrm{C}$ for $24 \mathrm{~h}$. In view of the excessive number of colonies, it was impossible to perform individual colony count (Fig. 1). Therefore, magnitude of growth was estimated as degrees of confluent growth.

All tests were performed three times, using fresh suspensions of Candida albicans prepared immediately before each inoculation.

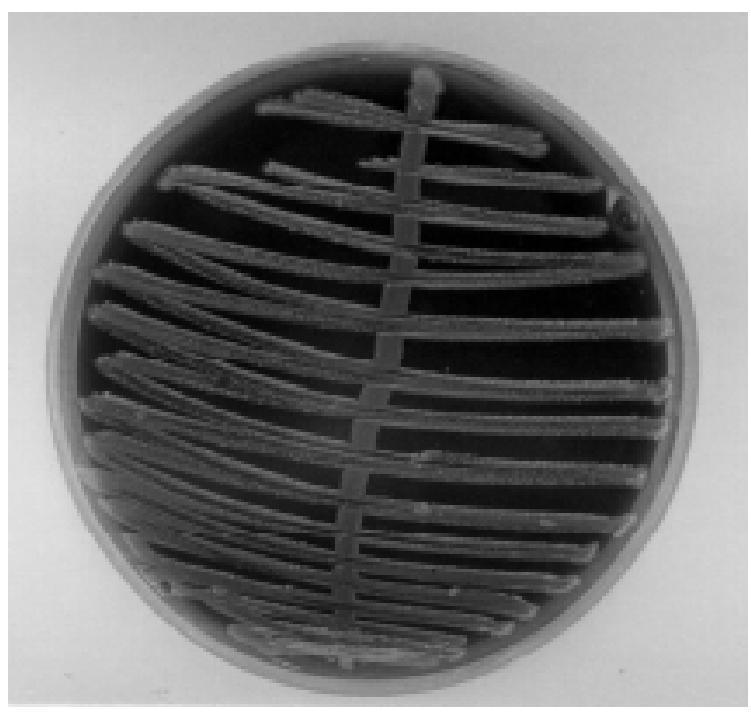

Figure 1 - Confluent growth of Candida albicans onto chocolate agar plates incubated for $24 \mathrm{~h}$ at $35^{\circ} \mathrm{C}$.

\section{RESULTS AND DISCUSSION}

Reports of blood culture using clinical specimens are sometimes difficult to interpret due to problems in standardization of blood samples. Another concern is that clinical specimens usually render a small number of positive cultures for a specific organism such as Candida albicans, and this has statistical implications. Furthermore, in the majority of the studies, the quantification of microorganisms in the sample was not performed $(3,19,26)$.

The methodology applied in this study allowed the use of equal volumes of blood in each method as well as inoculation of a previously established number of cells. The number of cells tested was related to those more frequently associated with candidemia $(14,26)$. Counts of 100 and 10 cells $/ \mathrm{ml}$ of blood were used to correspond to the counts observed in patients with infections related to catheters. Suspensions of 1 and 0.5 cells $/ \mathrm{ml}$ were used to resemble patients with candidemia related to other sources of infection (27).

Our results showed that it was possible to detect Candida albicans in blood, regardless both the number of cells and the methodology. In fact, the amount of colonies on agar chocolate plates in each dilution was comparable, despite the method employed (Table 1).

Table 1 - Growth on chocolate agar plates inoculated with sediment after concentration by Isolator ${ }^{\mathrm{TM}}$ and with conventional methods (broth and biphasic) previously incubated for $24 \mathrm{~h}$.

\begin{tabular}{lll}
\hline $\begin{array}{l}\text { Number of cells of } \\
\text { Candida albicans }\end{array}$ & Method & Growth \\
\hline 100 cells $/ \mathrm{ml}$ of blood & $\begin{array}{l}\text { Concentration } \\
\text { Conventional }\end{array}$ & $\begin{array}{l}\mathrm{P}+++ \\
\mathrm{P}+++\end{array}$ \\
10 cells $/ \mathrm{ml}$ of blood & $\begin{array}{l}\text { Concentration } \\
\text { Conventional }\end{array}$ & $\begin{array}{l}\mathrm{P}+++ \\
\mathrm{P}+++\end{array}$ \\
1 cell $/ \mathrm{ml}$ of blood & $\begin{array}{l}\text { Concentration } \\
\text { Conventional }\end{array}$ & $\mathrm{P}++$ \\
& $\mathrm{P}++$ \\
0.5 cells $/ \mathrm{ml}$ of blood & $\begin{array}{l}\text { Concentration } \\
\text { Conventional }\end{array}$ & $\mathrm{P}+$ \\
\hline
\end{tabular}

$\mathrm{P}=$ positive results: $+++/++=$ confluent growth $;+=$ uncountable colonies.

In order to determine the time required by each method to obtain positive results, we compared observations made in the first $24 \mathrm{~h}$ of test, i.e., presence of blastoconidia in Gram stain prepared from the conventional method with growth on solid media from the Isolator ${ }^{\mathrm{TM}}$. Blastoconidia were observed in all Gram stains and the number of yeast seen by microscopy was directly related to the original number of cells in the sample (Fig. 2).

According to our results, it appears reasonable to conclude that the concentration method alone did not 


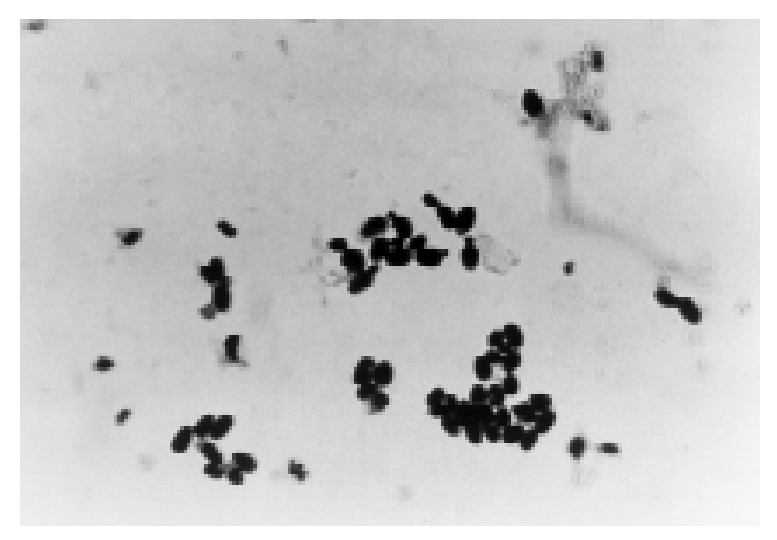

Figure 2 - Blastoconidia in Gram stain prepared from conventional methods after incubation for $24 \mathrm{~h}$ at $35^{\circ} \mathrm{C}$. Magnification, X 1000 .

reduce the time required for diagnosis, since positive results were obtained $24 \mathrm{~h}$ after inoculation of Candida albicans in both conventional and concentration methods. The mentioned advantage of Isolator ${ }^{\mathrm{TM}}$ in clinical reports may, therefore, be explained by the process of lysis which liberates microorganisms from phagocytes, increasing the number of viable yeasts $(19,35)$.

We suggest that the conventional method of growth in BHI for $24 \mathrm{~h}$, either in liquid or biphasic media, and the concentration method by Isolator ${ }^{\mathrm{TM}}$ display comparable ability for the recovery of yeasts from blood.

Although the process of concentration appears not to improve the recovery of Candida albicans from blood, other advantages of the Isolator ${ }^{\mathrm{TM}}$ system deserve consideration. Quantitative results, supplied by Isolator ${ }^{\mathrm{TM}}$, although unable to determine clinical importance of the microorganism, may be important to determine the source of the infection and to follow therapy $(26,34)$. It has to be considered, however, that quantitative results are difficult to interpret because the method is not reproducible, and routine variation in the concentration of yeasts in blood during the course of infection is not well delimited (34). Another advantage of Isolator ${ }^{\mathrm{TM}}$ is that direct inoculation of sediment onto agar plates would allow earlier isolation of colonies and a quicker identification (14). This, however, seems not to be so relevant as one can also obtain diagnosis of candidemia in the first $24 \mathrm{~h}$ through the visualization of blastoconidia directly in the broth of the conventional method, as we have demonstrated in this study.
Furthermore, identification and sensitivity tests can be done directly from broth (10).

Since concentration alone seems not improve the recovery of Candida albicans, the reported superiority of Isolator ${ }^{\mathrm{TM}}$ may be explained by lysis. Studies using conventional broth blood culture, supplemented with a lytic agent are therefore warranted. This will certainly be an enormous improvement for laboratories that use conventional methods.

\section{RESUMO}

\section{Processo de concentração do sangue na deteç̧ão de Candida albicans}

$\mathrm{O}$ sistema de lise-centrifugação (Isolator ${ }^{\mathrm{TM}}$ ) tem sido considerado como método padrão para aumentar as taxas de diagnóstico de candidemia através de hemocultura. Neste estudo, o processo de concentração, segundo este sistema, foi comparado com métodos convencionais de cultivo em meio líquido e bifásico. Foram realizados testes "in vitro" utilizando Candida albicans em contagens de 100, 10,1 e 0,5 células $/ \mathrm{ml}$ de sangue. Culturas em ágarchocolate foram realizadas a partir do sedimento obtido pela centrifugação do tubo de Isolator ${ }^{\mathrm{TM}} \mathrm{e}$ do caldo das culturas convencionais após sua incubação por 24 horas a $35^{\circ} \mathrm{C}$. Esfregaços corados pelo Gram, preparados a partir dos métodos convencionais, também foram observados em 24 horas. Foi possível detectar Candida albicans independentemente do número de células ou da metodologia utilizada. O tempo para diagnóstico também não foi diferente para os métodos comparados, já que blastoconídios e crescimento foram observados no mesmo prazo de tempo. Assim, sugerimos que o processo de concentração não é o maior fator responsável pelas taxas de recuperação de Candida albicans a partir do sangue obtidas pelo sistema Isolator ${ }^{\mathrm{TM}}$.

Palavras-chave: candidemia, hemocultura, sistema de lise-centrifugação.

\section{REFERENCES}

1. Beck-Sagué, C.M.; Jarvis, W.R. Secular trends in the epidemiology of nosocomial fungal infections in the United States, 1980-1990. J. Infect. Dis., 167:1247-51, 1993.

2. Belding, M.E.; Klebanoff, S.J. Effect of sodium polyanetholsulfonate on antimicrobial systems in blood. Appl. Microbiol., 24:691-8, 1972. 
3. Bille, J.; Edson, R.S.; Roberts, G.D. Clinical evaluation of the lysis-centrifugation blood culture system for the detection of fungemia and comparison with a conventional biphasic broth blood culture system. J. Clin. Microbiol., 19:126-8, 1984.

4. Bodey, G.P. Candidiasis - Pathogenesis, Diagnosis, and Treatment. 2.ed. New York, Raven Press, 1993. 420p.

5. Boschman, C.R.; Dressel, D.C.; Novak, C.C.; Hayden, R.T.; Peterson, L.R. Optimizing detection of microbial sepsis: a comparison of culture systems using packaged set with directions for blood collection. Diagn. Microbiol. Infect. Dis. 23:1-9, 1995

6. Braustein, H.; Tomasulo, M. A quantitative study of the growth of Candida albicans in vented and unvented blood culture bottles. Am. J. Clin. Pathol., 66:87-90, 1976.

7. Carvalho, W.F. Contagem das células sangüíneas. In: Técnicas médicas de hematologia e imuno-hematologia. 2.ed. Belo Horizonte, Coop. Ed. Cult. Médica, 1978. p. 54-65.

8. Cokerill, F.R.; Torgerson, C.A.; Reed, G.S.; Vetter, E.A.; Weaver, A.L.; Dale, J.C.; Roberts, G.C.; Henry, N.K.; Ilstrup, D.M.; Rosenblatt, J.E. Clinical comparison of Difco ESP, Wampole Isolator and Becton Dickinson Septi-Chek aerobic blood culturing systems. J. Clin. Microbiol. 34:20-24, 1996.

9. Creger, R.J.; Weeman, K.E.; Jacobs, M.R.; Morrissey, A.; Parker, P.; Fox, R.M.; Lazarus, H.M. Lack of utility of the lysiscentrifugation blood culture method for detection of fungemia in immunocompromised cancer patients. J. Clin. Microbiol., 36:290-3, 1998.

10. Doern, G.V. Manual blood culture systems and the antimicrobial removal device. Clin. Lab. Med., 14:133-47, 1994.

11. Dorn, G.L.; Burson, G.G.; Haynes, J.R. Blood culture technique based on centrifugation: clinical evaluation. J. Clin. Microbiol., 3:258-63, 1976.

12. Dunne, W.M.; Nolte, F.S.; Wilson, M.L. Blood cultures III Washington, D.C., American Society for Microbiology, 1997. 21p. (Cumitech 1B).

13. Engler, H.D; Fahke, G.A.; Gill, V.J. Clinical evaluation of the BacT/ Alert and Isolator aerobic blood culture systems. Am. J. Clin. Pathol. 105: 774-81, 1996

14. Geha, D.J.; Roberts, G.D. Laboratory detection of fungemia. Clin. Lab. Med., 14:83-97, 1994.

15. Kiehn, T.E.; Capitolo, C.; Mayo, J.B.; Armstrong, D. Comparative recovery of fungi from biphasic and conventional blood culture media. J. Clin. Microbiol., 14:681-3, 1981.

16. Leijh, P.C.J.; VanBarselaar, M.T.; VanFurth, R. Kinetics of phagocytosis and intracellular killing of Candida albicans by human granulocytes and monocytes. Infection and Immunity, 17:313-8, 1977

17. Lyon, R.; Woods, G. Comparison of the BacT/Alert and Isolator blood culture systems for recovery of fungi. Am. J. Clin. Pathol. 103:600-2, 1995 .

18. Morrell, R.M.; Wasilauskas, B.L.; Steffee, C.H. Performance of fungal blood cultures by using the Isolator collection system: is it cost-effective? J. Clin. Microbiol. 34:3040-43, 1996.
19. Murray, P.R.; Spizzo, A.W.; Niles, A.C. Clinical comparison of the recoveries of bloodstream pathogens in Septi-Chek brain heart infusion broth with saponin, Septi-Chek tryptic soy broth, and the Isolator lysis-centrifugation system. J. Clin. Microbiol., 29:901-5, 1991 .

20. Odds, F.C. Candida and candidosis. Leicester Univ. Press, London 1979. $382 \mathrm{p}$.

21. Pfaller, M.; Wenzel, R. Impact of the changing epidemiology of fungal infections in the 1990s. Eur. J. Clin. Microbiol. Infect. Dis., 11:287-91, 1992.

22. Pfaller, M.A. Laboratory aids in the diagnosis of invasive candidiasis. Mycopathology, 120:65-72, 1992.

23. Reimer, L.G.; Wilson, M.L.; Weinstein, M.P. Update on detection of bacteremia and fungemia. Clin. Microbiol. Rev., 10:444-65, 1997.

24. Schonheyder, H.C.; Hojbjerg, T. The impact of the first notification of positive blood cultures on antibiotic therapy. APMIS. 103:37-44, 1995.

25. Stamos, J.K.; Rowley, A.H. Candidemia in a pediatric population. Clin. Infect. Dis., 20:571-5, 1995.

26. Telenti, A.; Roberts, G.D. Fungal blood cultures. Eur. J. Clin. Microbiol. Infect. Dis., 8:825-31, 1989.

27. Telenti, A.; Steckelberg, J.M.; Stockman, L.; Edson, R.S.; Roberts, G.D. Quantitative blood cultures in candidemia. Mayo Clin. Proc., 66:1120-3. 1991

28. Walsh, T.J.; Pizzo, P.A. Nosocomial fungal infections: a classification for hospital-acquired fungal infections and mycoses arising from endogenous flora or reactivation. Ann. Rev. Microbiol., 42:517-45, 1988.

29. Wampole Laboratories Sample procedure manual format for Isolator $^{\mathrm{TM}} 10$ microbial tubes. Cranbury, N.J. 1994. p. 1-14.

30. Weinstein, M.P.; Reller, L.B.; Murphy, J.R.; Lichtenstein, K.A. The clinical significance of positive blood cultures: a comprehensive analysis of 500 episodes of bacteremia and fungemia in adults. I. Laboratory and epidemiologic observations. Rev. Infect. Dis., 5:35-53, 1983.

31. Wenzel, R.P.; Pfaller, M.A. Candida species: emerging hospital bloodstream pathogens. Infect. Control Hosp. Epidemiol., 12:523-4, 1991. [Editorial].

32. Wenzel, R.P. Nosocomial candidemia: risk factors and attributable mortality. Clin. Infect. Dis., 20:1531-4, 1995.

33. Wey, S.B.; Mori, M.; Pfaller, M.A.; Woolson, R.F.; Wenzel, R.P. Hospital-acquired candidemia: the attributable mortality and excess length of stay. Arch. Intern. Med., 148:2642-5, 1988.

34. Whimbey, E.; Wong, B.; Kiehn, T.E.; Armstrong, D. Clinical correlations of serial quantitative blood cultures determined by lysis-centrifugation in patients with persistent septicemia. $J$. Clin. Microbiol., 19:766-71, 1984.

35. Zierdt, C.H. Simplified lysed-blood culture technique. J. Clin. Microbiol., 23:452-5, 1986. 